\title{
Manipulated Crystallization and Passivated Defects for Efficient Perovskite Solar Cells via Addition of Ammonium Iodide
}

Wenjing Qi ${ }^{\mathrm{a}}$, Jiale Li ${ }^{\mathrm{a}}$, Yameng Li ${ }^{\mathrm{a}, \mathrm{b}}$, Khumal Sohaila, Hao Ling ${ }^{\mathrm{a}}$, Peng Wanga ${ }^{\mathrm{a}}$, Sumin Jiao ${ }^{\mathrm{a}, \mathrm{b}}$, Fan Liu ${ }^{\mathrm{a}, \mathrm{c}}$, Xin Zhou ${ }^{\mathrm{a}}$, Huanhuan Wanga, Dekun Zhang ${ }^{\mathrm{a}}$, Yi Ding ${ }^{\mathrm{a}}$, Xinliang Chen ${ }^{\mathrm{a}}$, Guofu Hou ${ }^{\mathrm{a}}$, Jingshan $\mathrm{Luo}^{\mathrm{a}}$, Ying Zhao ${ }^{\mathrm{a}}$, Yuelong Li*a, Xiaodan Zhang ${ }^{\mathrm{a}}$

${ }^{a}$ Institute of Photoelectronic Thin Film Devices and Technology of Nankai University, Solar Energy Research Center of Nankai University, Key Laboratory of Photoelectronic Thin Film Devices and Technology of Tianjin, Engineering Research Center of Thin Film Optoelectronics Technology, Ministry of Education, \#38 Tongyan Road, Jinnan District, Tianjin 300350, China.

b College of Chemical and Pharmaceutical Engineering, Hebei University of Science and Technology, \#26 Yuxiang Street, Yuhua District, Shijiazhuang 050018, China.

c College of Mechanical Engineering, Guizhou University, Guiyang 550025, China.

*E-mail: lyl@nankai.edu.cn (Prof. Y. Li). 

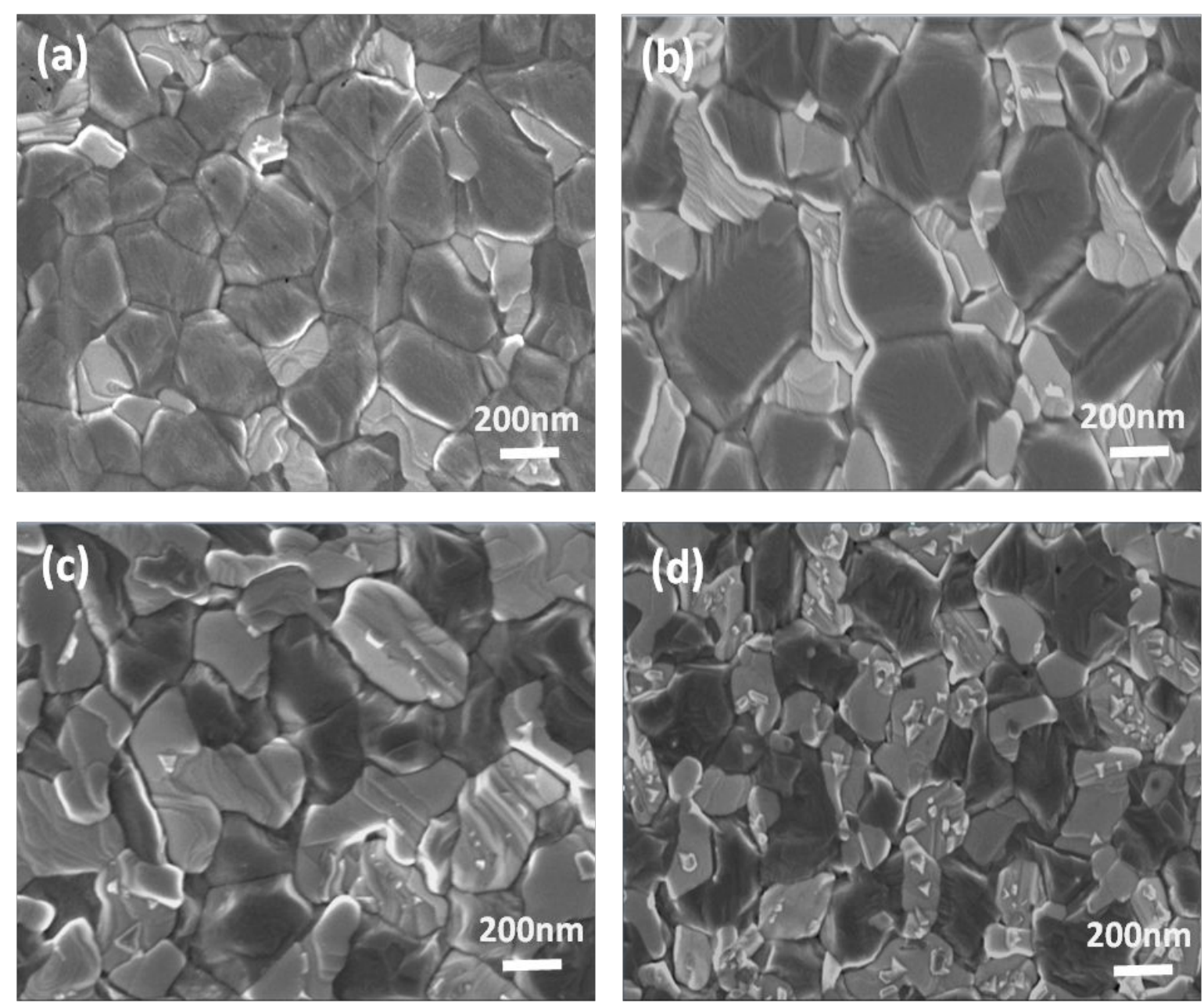

Figure S1. SEM images of the films of (a) the control, (b) $1 \mathrm{mg} / \mathrm{ml}$, (c) $2 \mathrm{mg} / \mathrm{ml}$, and (d) $3 \mathrm{mg} / \mathrm{ml} \mathrm{NH}_{4} \mathrm{I}$ added films. 


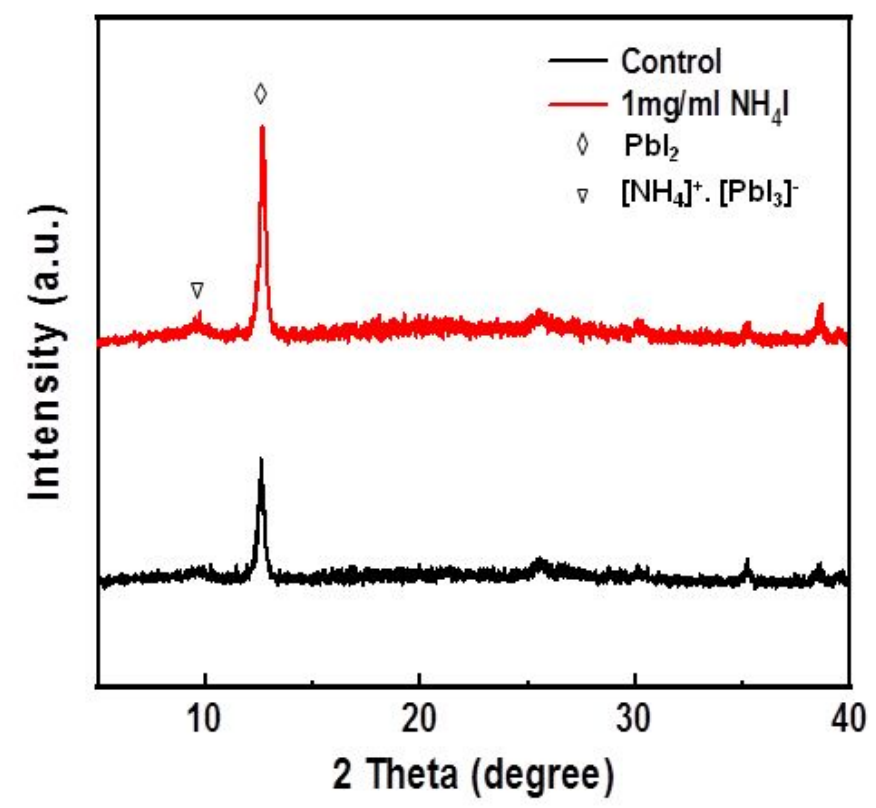

Figure S2. $\mathrm{XRD}$ of $\mathrm{PbI}_{2}$ film with and without $\mathrm{NH}_{4} \mathrm{I}$.
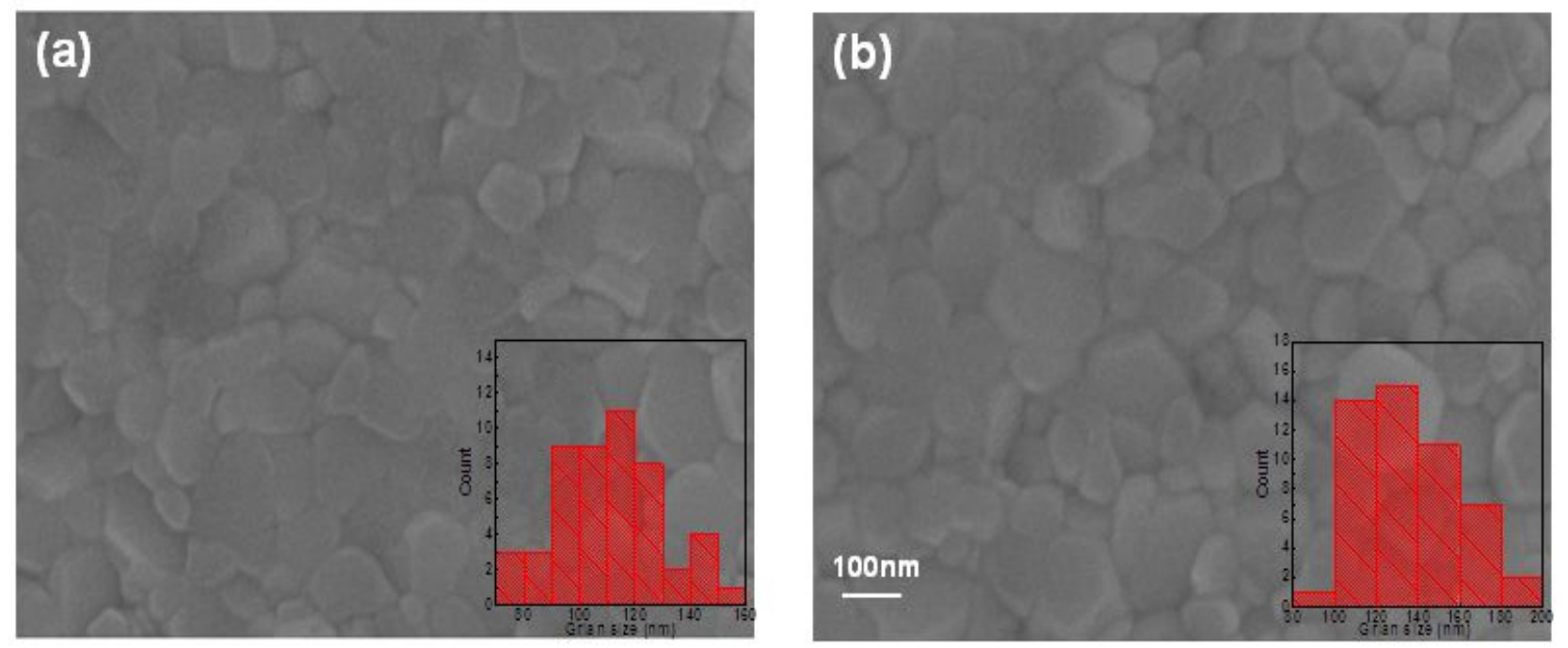

Figure S3. SEM images of the $\mathrm{PbI}_{2}$ films of (a) the control and (b) $1 \mathrm{mg} / \mathrm{ml} \mathrm{NH}_{4} \mathrm{I}$ added. The illustration are the histogram of grain size. 


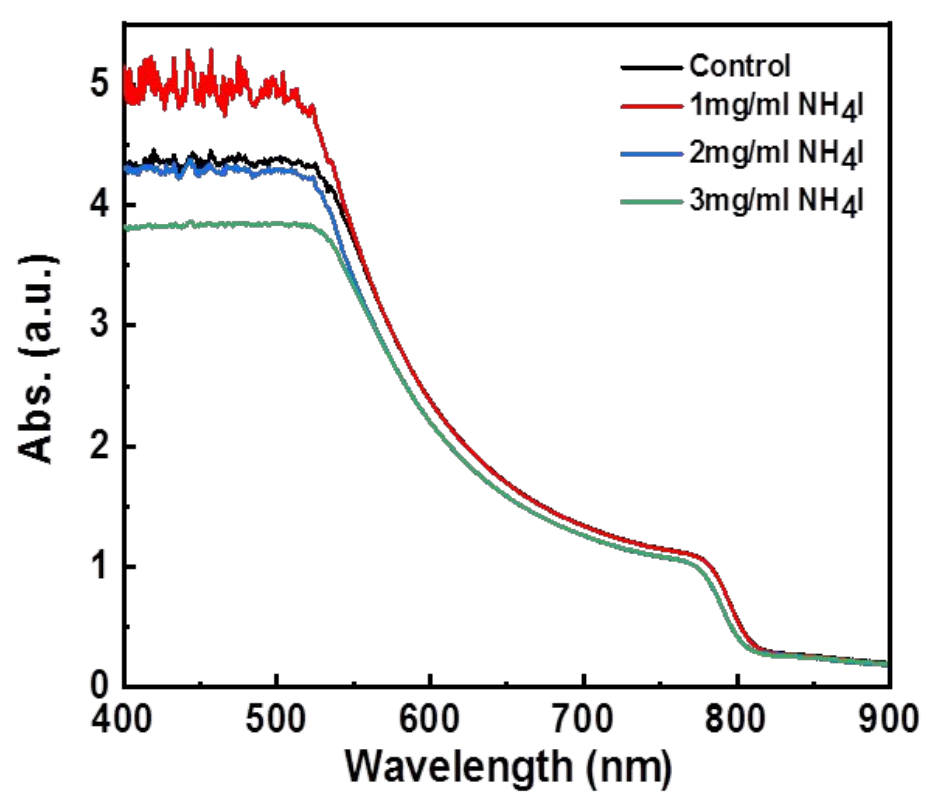

Figure S4. UV-vis absorption spectra of perovskite film with the control, $1 \mathrm{mg} / \mathrm{ml}, 2 \mathrm{mg} / \mathrm{ml}, 3 \mathrm{mg} / \mathrm{ml} \mathrm{NH} \mathrm{N}_{4} \mathrm{I}$ added.
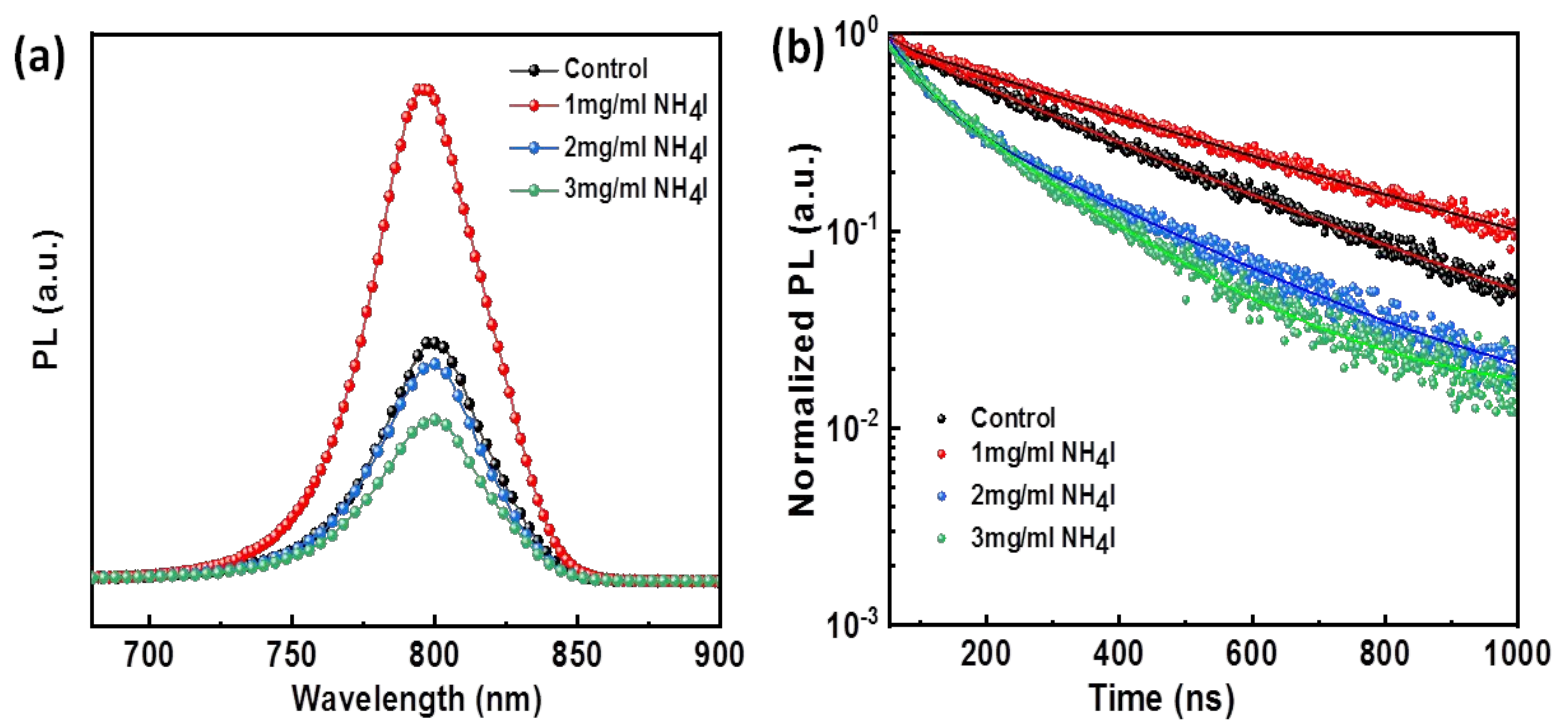

Figure S5. The steady-state photoluminescence (PL) in (a) and time-resolved PL (TRPL) spectra in (b) of control, $1 \mathrm{mg} / \mathrm{ml}, 2 \mathrm{mg} / \mathrm{ml}, 3 \mathrm{mg} / \mathrm{ml} \mathrm{NH}_{4} \mathrm{I}$ added film with a structure of glass /perovskite. 

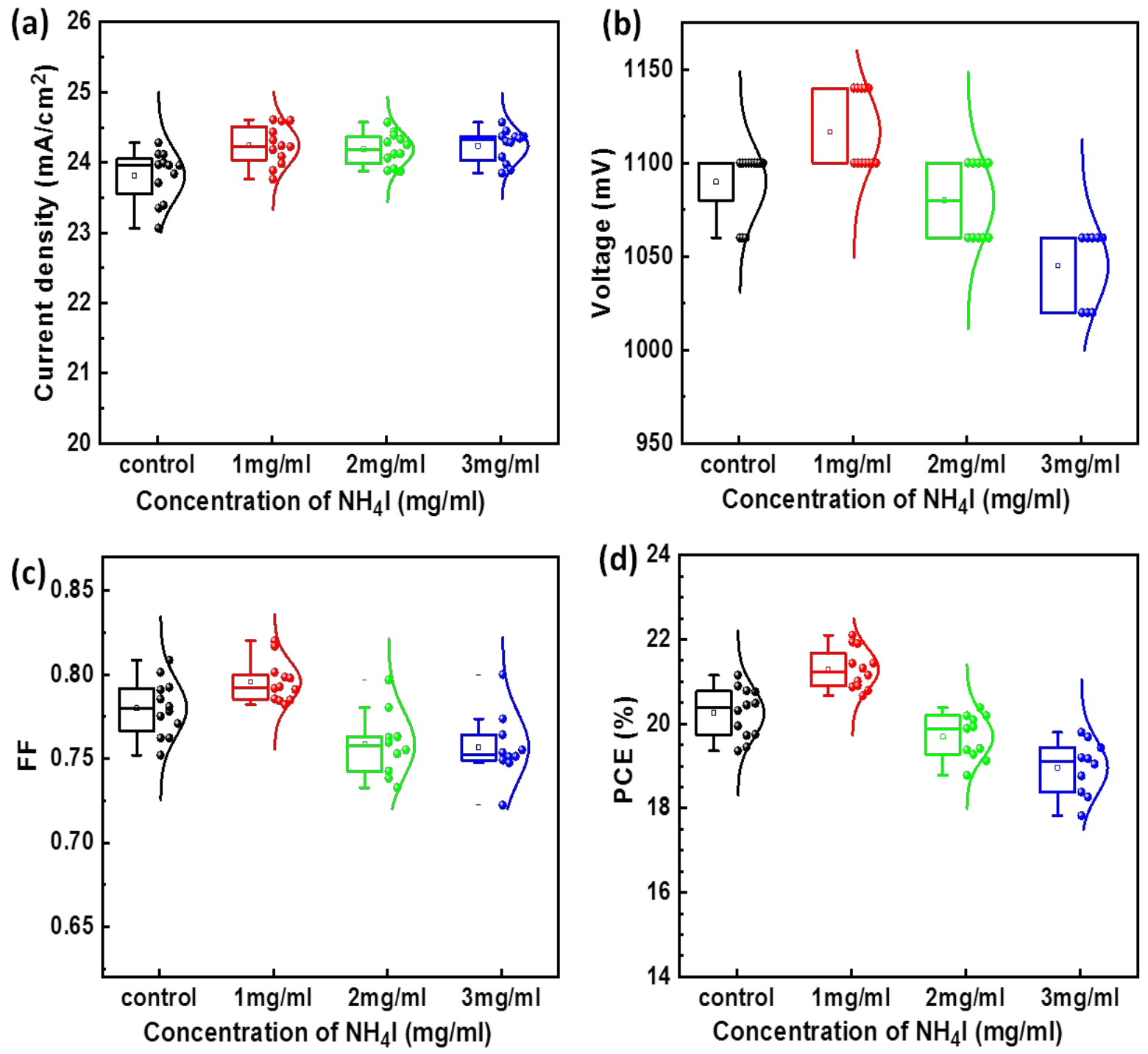

Figure S6. (a-d) Statistical distribution of photovoltaic parameters of perovskite solar cells made of control films and films added with different concentrations of $\mathrm{NH}_{4} \mathrm{I}$. In order to improve the overall efficiency, all perovskite films are further treated with PEAI as the passivation layer.

Table S1. The detailed photovoltaic parameters of perovskite solar cells with various concentration of $\mathrm{NH}_{4} \mathrm{I}$ added.

The statistic values are calculated based on at least 10 samples for each condition.

\begin{tabular}{lllllll}
\hline Sample & Scan & $J_{\text {SC }}$ & V & FF (\%) & PCE (\%) & Best \\
& & & & & \\
\hline
\end{tabular}




\begin{tabular}{lcccccc}
\hline & direction & $\left(\mathbf{m A} / \mathbf{c m}^{2}\right)$ & $(\mathbf{V})$ & & & PCE (\%) \\
\hline \multirow{2}{*}{ Control } & RS & $23.62 \pm 0.32$ & $1.09 \pm 0.02$ & $77.7 \pm 1.8$ & $20.12 \pm 0.46$ & 21.47 \\
& FS & $23.81 \pm 0.40$ & $1.08 \pm 0.02$ & $78.2 \pm 1.6$ & $20.26 \pm 0.50$ & 21.15 \\
& RS & $24.25 \pm 0.29$ & $1.13 \pm 0.02$ & $79.4 \pm 1.3$ & $21.36 \pm 0.57$ & 22.15 \\
$1 \mathrm{mg} / \mathrm{ml}$ & FS & $24.24 \pm 0.31$ & $1.11 \pm 0.02$ & $79.6 \pm 1.7$ & $21.29 \pm 0.41$ & 22.10 \\
& RS & $24.18 \pm 0.23$ & $1.08 \pm 0.02$ & $76.1 \pm 2.3$ & $19.97 \pm 0.56$ & 20.71 \\
& FS & $24.13 \pm 0.20$ & $1.07 \pm 0.02$ & $75.5 \pm 1.7$ & $19.77 \pm 0.58$ & 20.38 \\
& & & & & & \\
$3 \mathrm{mg} / \mathrm{ml} / \mathrm{ml}$ & RS & $24.22 \pm 0.13$ & $1.05 \pm 0.03$ & $75.5 \pm 2.0$ & $19.03 \pm 0.63$ & 19.83 \\
& FS & $24.31 \pm 0.30$ & $1.06 \pm 0.03$ & $75.2 \pm 1.8$ & $18.88 \pm 0.72$ & 19.79 \\
\hline
\end{tabular}
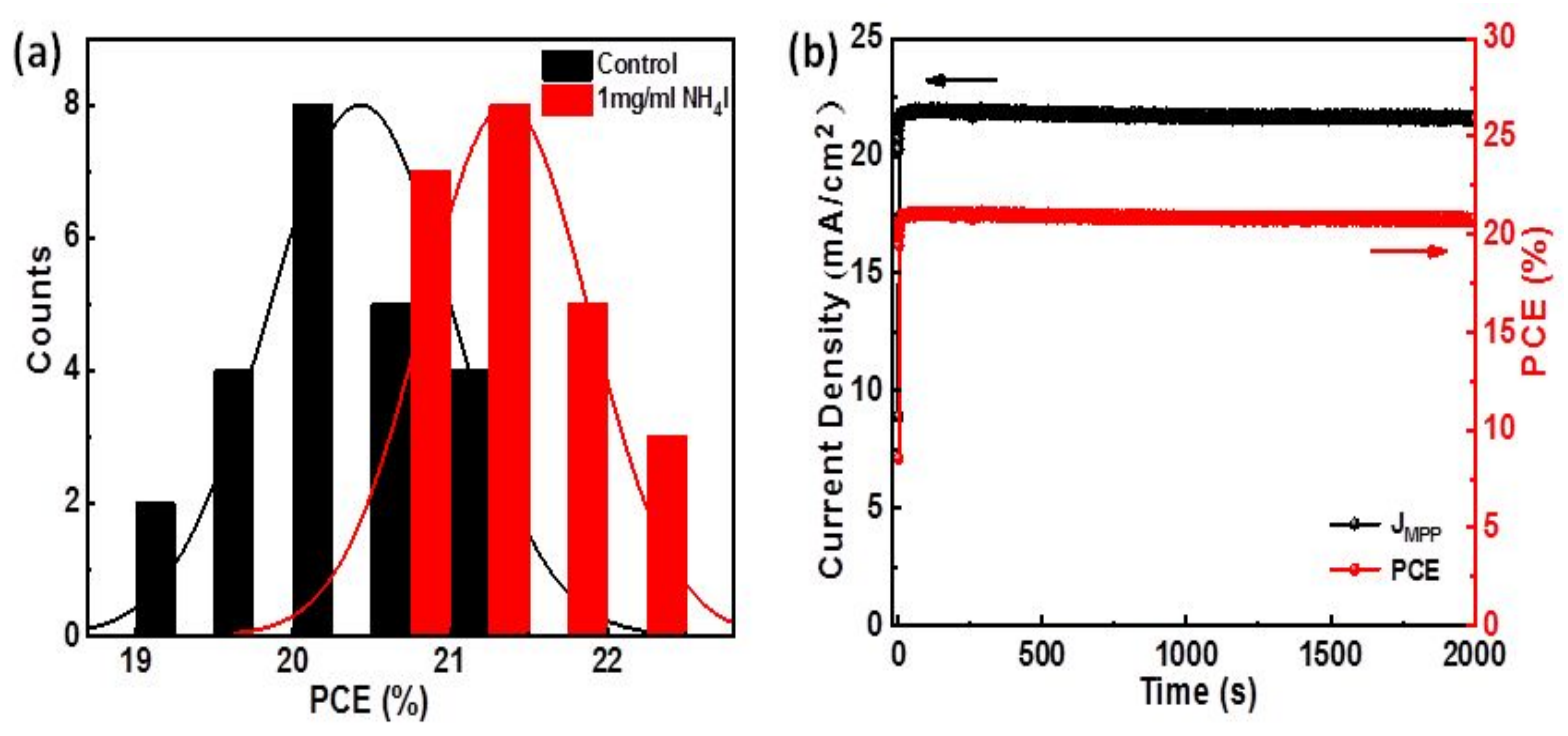

Figure S7. (a) Efficiency distribution histogram of the 25 cells prepared with the conditions of the control and 1 $\mathrm{mg} / \mathrm{mL} \mathrm{NH}_{4} \mathrm{I}$ added. (b) The maximum power point tracking curves of perovskite solar cell with $\mathrm{NH}_{4} \mathrm{I}$ treated for 2000s under continuous one sun illumination. 
In addition, we also tried to dissolve $\mathrm{NH}_{4} \mathrm{I}$ in isopropanol (IPA) with various concentration, and then spin-coated them on the top of $\mathrm{SnO}_{2}$ layer or the perovskite layer for interfacial modification or passivators, resulting in slightly improved performance, but not as effective as that of dissolving $\mathrm{NH}_{4} \mathrm{I}$ directly into $\mathrm{PbI}_{2}$ solution. We also tested the effect of applying $\mathrm{NH}_{4} \mathrm{I}$ as multifunctional passivation, that is $0.5 \mathrm{mg} / \mathrm{ml} \mathrm{NH} 4 / / \mathrm{IPA}$ is added on the $\mathrm{SnO}_{2}$ layer and perovskite layer and $1 \mathrm{mg} / \mathrm{ml} \mathrm{NH}_{4} \mathrm{I} / \mathrm{DMF}$ mixed into the $\mathrm{PbI}_{2}$ solution simultaneously. The results show no apparently superior to that of only adding $\mathrm{NH}_{4} \mathrm{I}$ to the $\mathrm{PbI}_{2}$ solution. The photovoltaic parameters of the corresponding devices are summarized in Table S2, and then graphically compared in Figure S7. Therefore, we finally chose to dope $\mathrm{NH}_{4} \mathrm{I}$ into $\mathrm{PbI}_{2}$ layer for controlling the transforming kinetics and passivation of the perovskite layer. 
(a)

(c)
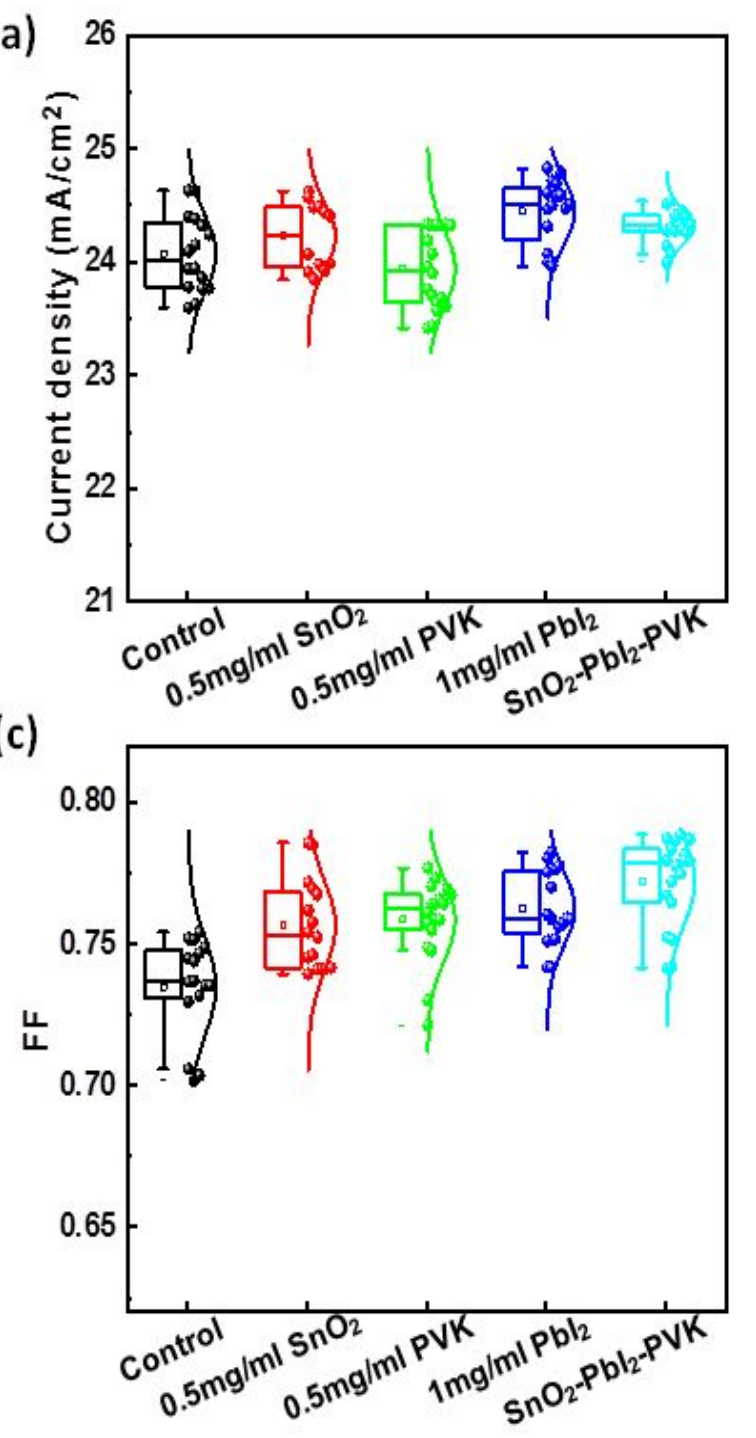

(b)

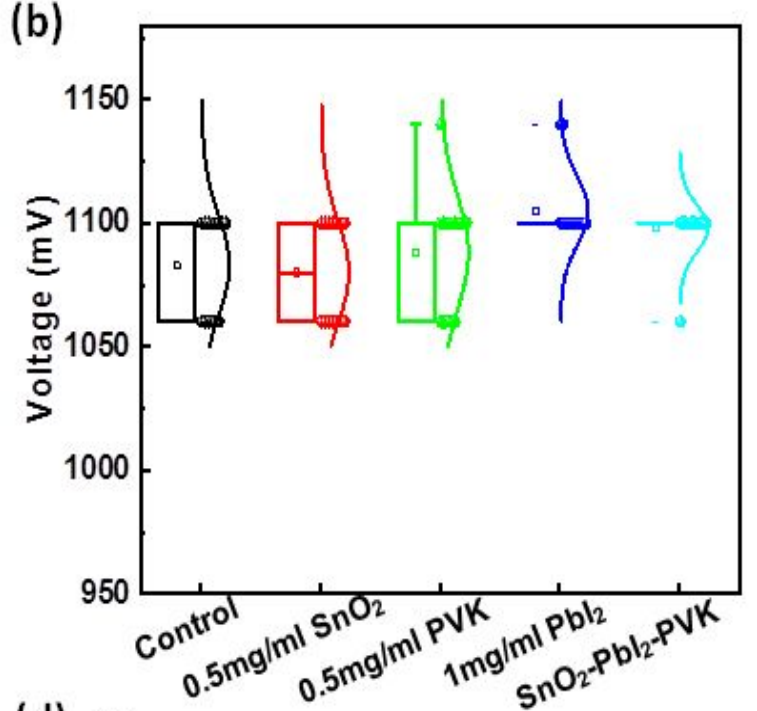

(d)

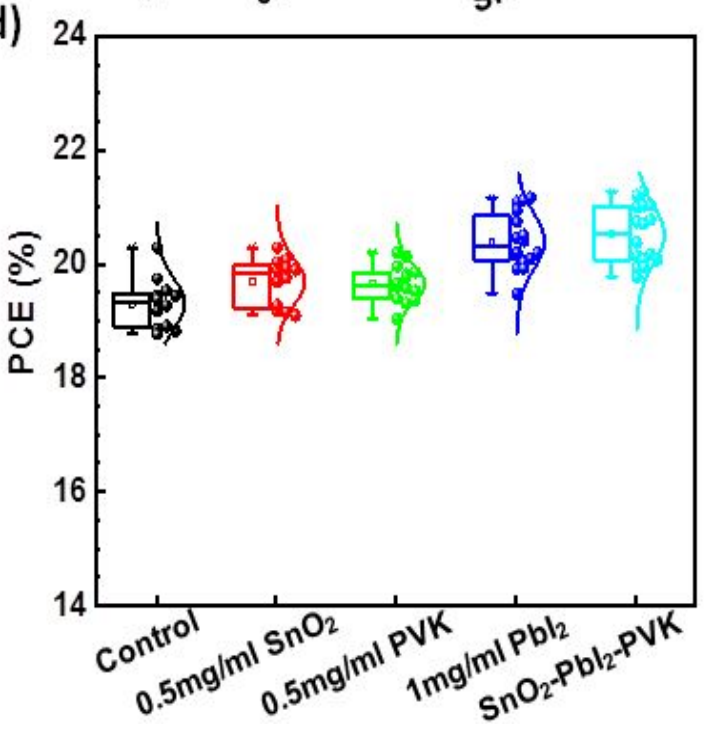

Figure S8. (a-d) Statistics distribution of photovoltaic parameters of devices through adding $\mathrm{NH}_{4} \mathrm{I}$ to different functional layers: (1) the control device; (2) $0.5 \mathrm{mg} / \mathrm{ml} \mathrm{NH} 4 / \mathrm{IPA}$ is spin-coated on the top of $\mathrm{SnO}_{2}$ layer; (3) $0.5 \mathrm{mg} / \mathrm{ml} \mathrm{NH}_{4} \mathrm{I} / \mathrm{IPA}$ is spin-coated on the top of perovskite layer; (4) $1 \mathrm{mg} / \mathrm{ml} \mathrm{NH} \mathrm{NH}_{4} / \mathrm{DMF}$ is added to the $\mathrm{PbI}_{2}$ solution; (5) Applying $\mathrm{NH}_{4} \mathrm{I}$ to three different functional layers simultaneously. During this optimizing process, the devices are not post-treated by PEAI. 
Table S2. The detailed photovoltaic parameters of perovskite solar cells with various conditions. The statistic values are calculated based on at least 10 samples for each condition.

\begin{tabular}{|c|c|c|c|c|c|c|}
\hline Sample & $\begin{array}{c}\text { Scan } \\
\text { direction }\end{array}$ & $\begin{array}{c}\mathrm{J}_{\mathrm{SC}} \\
\left(\mathbf{m A} / \mathbf{c m}^{2}\right)\end{array}$ & $\begin{array}{l}\mathbf{V}_{\text {OC }} \\
(\mathrm{V})\end{array}$ & FF (\%) & PCE (\%) & $\begin{array}{c}\text { Best } \\
\text { PCE }(\%)\end{array}$ \\
\hline \multirow{2}{*}{ Control } & RS & $24.07 \pm 0.35$ & $1.08 \pm 0.02$ & $73.3 \pm 1.9$ & $19.24 \pm 0.37$ & 19.74 \\
\hline & FS & $23.94 \pm 0.34$ & $1.08 \pm 0.02$ & $73.6 \pm 1.6$ & $19.36 \pm 0.53$ & 20.28 \\
\hline $0.5 \mathrm{mg} / \mathrm{ml}$ & RS & $24.25 \pm 0.30$ & $1.08 \pm 0.02$ & $75.5 \pm 1.2$ & $19.73 \pm 0.45$ & 20.32 \\
\hline$@ \mathrm{SnO}_{2}$ & FS & $24.20 \pm 0.32$ & $1.07 \pm 0.02$ & $75.8 \pm 1.9$ & $19.65 \pm 0.41$ & 20.03 \\
\hline $0.5 \mathrm{mg} / \mathrm{ml}$ & RS & $23.84 \pm 0.33$ & $1.09 \pm 0.03$ & $76.0 \pm 0.6$ & $19.82 \pm 0.32$ & 20.22 \\
\hline$@ \mathrm{PVK}$ & FS & $23.81 \pm 0.31$ & $1.08 \pm 0.02$ & $75.6 \pm 1.9$ & $19.49 \pm 0.25$ & 19.81 \\
\hline $1 \mathrm{mg} / \mathrm{ml}$ & RS & $24.46 \pm 0.28$ & $1.11 \pm 0.02$ & $76.3 \pm 1.0$ & $20.67 \pm 0.37$ & 21.17 \\
\hline in $\mathrm{PbI}_{2}$ & FS & $24.42 \pm 0.32$ & $1.10 \pm 0.01$ & $76.2 \pm 1.6$ & $20.13 \pm 0.47$ & 21.13 \\
\hline $\mathrm{SnO}_{2}-\mathrm{PbI}_{2}-\mathrm{P}$ & RS & $24.31 \pm 0.13$ & $1.10 \pm 0.01$ & $76.9 \pm 1.2$ & $20.43 \pm 0.49$ & 21.02 \\
\hline $\mathrm{VK}$ & FS & $24.37 \pm 0.17$ & $1.09 \pm 0.01$ & $77.4 \pm 1.8$ & $20.60 \pm 0.53$ & 21.27 \\
\hline
\end{tabular}
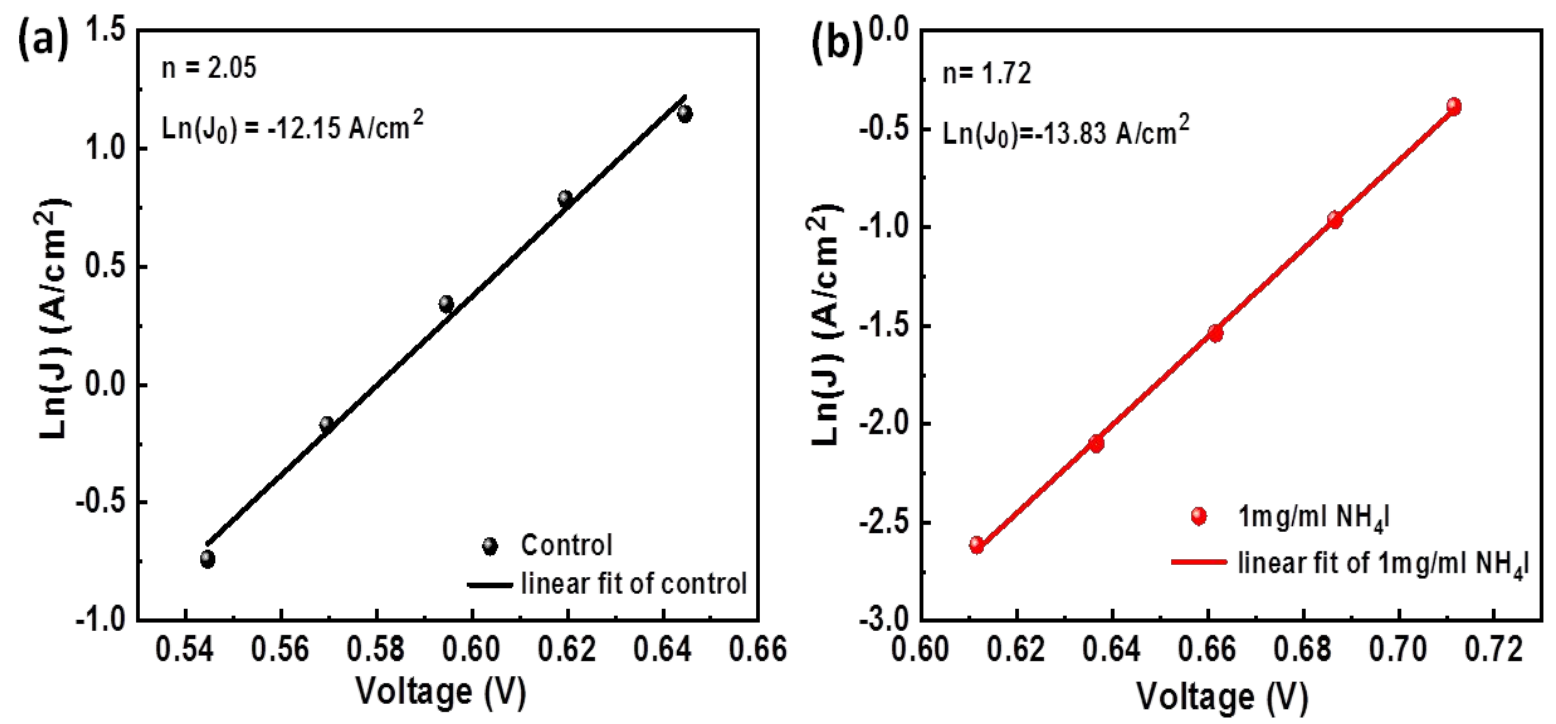
Figure S9. Fitted curves corresponding to dark $J-V$ in Figure $4 \mathrm{~b}$ for calculating the value of $n$ of the control device (a) and $1 \mathrm{mg} / \mathrm{mL} \mathrm{NH}_{4} \mathrm{I}$ added perovskite solar cells (b), respectively.

Table S3. The EIS parameters of the control and $1 \mathrm{mg} / \mathrm{ml} \mathrm{NH} \mathrm{H}_{4} \mathrm{I}$ added devices.

\begin{tabular}{cccccc}
\hline Sample & $\mathbf{R}_{\mathbf{s}}(\boldsymbol{\Omega})$ & $\mathbf{R}_{\mathbf{t r}}(\boldsymbol{\Omega})$ & $\mathbf{C}_{\mathbf{t r}}(\mathbf{n F})$ & $\mathbf{R}_{\mathrm{re}}(\boldsymbol{\Omega})$ & $\mathbf{C}_{\mathbf{t r}}(\mathbf{n F})$ \\
\hline Control & 21.15 & 51.19 & 14.34 & 770 & 10.37 \\
$1 \mathrm{mg} / \mathrm{ml} \mathrm{NH}_{4} \mathrm{I}$ & 20.51 & 34.14 & 54.22 & 1444 & 8.24 \\
\hline
\end{tabular}

